\title{
ПИТАННЯ СТАТЕВОГО ВИХОВАННЯ МОЛОДІ ДОНЕЦЬКОГО РЕГІОНУ
}

\author{
Хапченкова Д. С., асистент кафедри анатомії людини, лікар педіатр \\ Дубина С. О., к.мед.н., дочент, завідуючий кафедрою анатомії людини \\ Бондаренко С. В., асистент кафедри анатомії людини
}

Украйна, Лиман, Донеиький начіональний медичний університет МОЗ Украйни, кафедра анатомії людини

DOI: https://doi.org/10.31435/rsglobal_ws/30122019/6834

\begin{abstract}
ARTICLE INFO
Received: 19 October 2019

Accepted: 14 December 2019

Published: 30 December 2019

\section{KEYWORDS}

young people,

sexual education,

problematic issues.

ABSTRACT

Sex education is an integral part of the overall school and family upbringing process. One of the main tasks of modern domestic educational institutions is properly organized education in the sexual sphere. The goal of sexual education and preparation for family life should be the prevention and correction of major sexual behavior. The article presents the survey results on the issues of sexual education of young people in Donetsk region at the present stage. Problematic issues were identified regarding sexual education, contraception, family planning and obtaining information about sexually transmitted diseases based on an anonymous survey conducted by medical university students. The main directions of educational work concerning these issues are identified.
\end{abstract}

Citation: Хапченкова Д. С., Дубина С. О., Бондаренко С. В. (2019) Issues of Sexual Education of Young People in Donetsk Region. World Science. 12(52), Vol.2. doi: 10.31435/rsglobal_ws/30122019/6834

Copyright: () 2019 Хапченкова Д. С., Дубина С. О., Бондаренко С. В. This is an open-access article distributed under the terms of the Creative Commons Attribution License (CC BY). The use, distribution or reproduction in other forums is permitted, provided the original author(s) or licensor are credited and that the original publication in this journal is cited, in accordance with accepted academic practice. No use, distribution or reproduction is permitted which does not comply with these terms.

Вступ. Статеве виховання - це складова частина загального процесу виховання в школі та сім'ї, спрямована на формування свідомості молоді відповідно до ії статі та оволодіння нею культурою міжстатевих стосунків відповідно до загальноприйнятої системи статевих ролей [1].

Соціально-економічні зміни сучасного суспільства, посилений вплив зарубіжної культури спричинили знецінення українських вартостей, зменшення ролі родини у процесі виховання молоді, що призвело до загального зниження народжуваності, зростання кількості розлучень та неповних сімей, нестабільності подружніх взаємин, раннього початку статевого життя, збільшення кількості небажаної вагітності та абортів, поширення захворювань, що передаються статевим шляхом [2]. У зв'язку з цим одним із основних завдань сучасних вітчизняних навчальних закладів $\epsilon$ правильно організоване виховання у статевій сфері, де провідну роль відводять освітнім закладам різного рівня [3]. Кінцевою метою статевого виховання, сексуальної освіти і підготовки до сімейного життя повинні ставати профілактика і корекція великого розвитку сексуальної поведінки, а також збереження та зміцнення сексуального і репродуктивного здоров'я людини, підготовка молоді до виконання сімейних (подружніх і батьківських) ролей, що $є$ необхідним компонентом соціального здоров'я суспільства [4].

Серед сучасних важливих педагогічних та суспільних проблем $\epsilon$ ранній початок неповнолітніми статевого життя, що супроводжується зростанням кількості штучного переривання вагітності, збільшенням частоти венеричних захворювань, появою серед школярок матеріводиначок [5]. Актуальність проблеми статевого виховання зумовлена також некомпетентністю педагогів, батьків у питаннях сексуальної просвіти, що призводить до відсутності ранньої орієнтації на виконання соціальної ролі в житті (батька, матері, дружини, чоловіка) [1].

Мета: визначити проблемні питання статевого виховання серед молоді. 
Матеріали та методи: проведено анонімне анкетування студентів першого курсу медичного факультету № 1 Донецького національного медичного університету. В опитуванні прийняли участь 52 студента (26 дівчат та 26 юнаків). Під час анкетування респондентам пропонували зазначити свій вік та стать, наявність статевих відносин, перерахувати джерела 3 яких студент отримував інформацію про статеве виховання, засоби та методи контрацепції, перелік захворювань, що передаються статевим шляхом. Також пропонували відзначити 3 якого віку і в якому вигляді, на думку респондентів, повинні проводитися заходи щодо статевого виховання молоді на сучасному етапі.

Результати та їх обговорення. Вік респондентів склав від 17 до 20 років. Більшість студентів (31 особа - 59,61\%) на момент опитування не мали інтимних відносин (15 юнаків та 16 дівчат). Інформацію про статеве виховання отримували з різних джерел: від батьків та інтернету -9 студентів, тільки з інтернет-ресурсів - 31 респондент, з підручників -5 студентів та від друзів або знайомих -7 осіб. Жоден студент не відвідував лікарень дружніх до молоді, не приймав участі у тренінгах стосовно контрацепції та планування сім'і (18 студентів - 34, 61\% навіть не знали про їх існування та проведення). При цьому велика частка опитаних (28 осіб - 53, 84\%) зауважували на брак достовірної інформації щодо контрацепції, захворювань, що передаються статевим шляхом та їх подальшого впливу на організм. При виникненні питань інтимного характеру 20 студентів $(38,46 \%)$ в першу чергу зверталися до інтернет-видань, стидаючись звернутися до медичних закладів, тому що не вірили в анонімність та збереження лікарської таємниці. Більшість студентів (42 особи $-80,76 \%$ ) відмічали необхідність раннього статевого виховання з 9-10-річного віку, для уникнення «незручних» питань до батьків та товаришів. На думку опитаних лекції та презентації в школах, тренінги в навчальних закладах повинні проводити тільки медичні працівники, викладачі вищих медичних навчальних установ обов'язково з залученням психологів 3 наведенням клінічних випадків, використанням мультимедійних засобів, привертаючи в обговорення слухачів та активно визначати проблемні питання серед молоді. Аудиторія повинна приймати участь в обговоренні проблем, що турбують індивідуально кожного, разом знаходити шляхи їх вирішення, подолання життєвих труднощів. Враховуючи стрімкий фізичний розвиток, психоемоційний бік сучасної молоді зазнає великої енергетичної недостатності. Внаслідок чого з'являється невпевненість у власних силах, неспроможність долати життєві труднощі, «штучне» закриття своїх почуттів від оточуючих. Стійкість у подоланні труднощів, збереження віри в себе, впевненості в собі, своїх можливостях, досконалість психічної саморегуляції, постійний досить високий рівень настрою ось невід'ємні складові сучасного психічного життя. Здатність зберігати постійний рівень настрою без звернення до психоактивних речовин і бути чутливим до різних аспектів життя, мати різнобічні інтереси - також вважливі складові психологічної стійкості, які потребують корекції у молоді [5].

Висновки. Незважаючи на швидкий розвиток сучасності і обумовлені цим зміни у житті людини, деякі питання стосовно статевого виховання підлітків залишаються невирішеними. Недостатня інформованість, недовіра до лікарів, зайнятість батьків та як наслідок відсутність уваги з їх боку, призводять до великої кількості помилок «дорослого життя〉 серед молоді. Зростає необхідність виховання дітей починаючи з шкільного віку, пошук та впровадження нових сучасних методів формування статевої обізнаності. Програма статевого виховання і сексуальної освіти повинна охоплювати нерозривно пов'язані між собою інформаційно-просвітницький та інструментальний і виховний компоненти, що забезпечують формування у підлітків адекватних етичних норм, ціннісних орієнтацій, знань і навичок, прийнятих на особистісному рівні і реалізованих у подальшому дорослому житті.

\section{REFERENCES}

1. Leshchuk N.O., Savych Zh. V., Holotsvan O. A., Syvokhop Ya. M. (2014) Stateve vykhovannia i reproduktyvne zdorovia pidlitkiv ta molodi : navch. posib. $136 \mathrm{~s}$.

2. Bialyk O. V. (2017) Suchasni tendentsii statevoho vykhovannia uchnivskoi molodi $\mathrm{v}$ krainakh Yevrosoiuzu: dys. ... dok. ped. nauk. 547.

3. Loktieva S.A. (2009) Rozvytok osobystosti y adaptatsiia v studentskomu seredovyshchi / Naukove opysannia NPU imeni M.P. Drahomanova. Psykholohichni nauky: Zb. naukovykh prats. K.: NPU imeni M.P. Drahomanova. 24:78 -82.

4. Vasylenko O. V. (2006) Pedahohichni umovy statevoho vykhovannia starshykh pidlitkiv u pozaurochnii diialnosti: dys. ... kand. ped. nauk. 225 s.

5. Kulykova N. V. (2011) Zdorovbi obraz zhyzny: ucheb. posobye. Ch. 2. Tomsk: Yzd-vo Tomskoho hos. ped. un-ta. 76. 